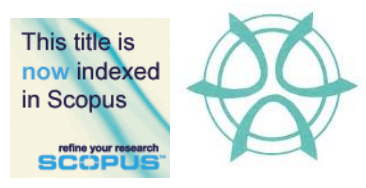

PLANNING MALAYSIA:

Journal of the Malaysian Institute of Planners

VOLUME 15 ISSUE 1 (2017), Page 21 - 30

\title{
A THEORETICAL ASSESSMENT ON SUSTAINABLE WELLBEING INDICATORS FOR PEOPLE INTERRELATIONSHIPS
}

\author{
Aisyah Abu Bakar', Mariana Mohamed Osman², Syahriah Bachok ${ }^{3}$, Ismawi Zen ${ }^{4}$, \\ Alias Abdullah ${ }^{5}$, \& Muhammad Faris Abdullah ${ }^{6}$ \\ 1,2,3,4,5,6 Kulliyyah of Architecture and Environmental Design, \\ INTERNATIONAL ISLAMIC UNIVERSITY MALAYSIA
}

\begin{abstract}
Sustainable well-being is the well-being attained without compromising others' opportunities to pursue their happiness. The concept of well-being is not merely personal, relational, organizational or communal issues, but rather the synergy of all four dimensions. The four dimensions of well-being are distinguishable, but they are inseparable entities. While focusing on subjective measure of well-being some research fail to interrogate the influence of contextual dynamics on respondents who report high levels of well-being despite living in deprived community conditions. This study argues that there could not be well-being without the combination of personal, relational, organizational and communal wellness.
\end{abstract}

Keyword: sustainable well-being, human interrelationships with other humans.

Date Received: $30^{\text {th }}$ April 2016

Date of Acceptance: $30^{\text {th }}$ October 2016 
Aisyah Abu Bakar, Mariana Mohamed Osman, Syahriah Bachok, Ismawi Zen, Alias Abdullah, \& Muhammad Faris Abdullah A Theoretical Assessment on Sustainable Wellbeing Indicators for People Interrelationships

\section{INTRODUCTION}

This study establishes the theoretical framework of human interrelationships with other humans as an important component of sustainable well-being. Sustainable well-being is the achieved well-being without compromising others' opportunity to pursue their well-being. The study is a part of an ongoing pursuit to discover subjective indicators of sustainable well-being that manifests in (i) human interrelationships with other humans, and (ii) human interrelationships with the environment. This paper focuses on human interrelationships with other humans.

Malaysia Well-Being Report 2013 (MWI, 2013) prepared by Economic Planning Unit (EPU) reported the social progress of Malaysia under eight Social Well-Being components. However, EPU admitted that the reports cannot cover all aspects of wellbeing (MQLR 2004; MQLR 2011). These refer to the nonquantifiable aspects such as the harmony of the country, work ethics, and communal values. On June 2014, EPU inquired researchers to discover what matter most to the citizens.

Many research focusing on subjective well-being measures failed to interrogate the influence of contextual dynamics on respondents who report high levels of well-being despite living in deprived conditions (Prilleltensky \& Fox, 2007). There are two interesting and debatable possibilities of the mentioned problem. The first possibility is that the poor people could be genuinely experienced a high level of well-being despite living in underprivileged conditions. The second possibility is that the poor people refused to be portrayed as the object of pity (Haworth \& Hart, 2007). Eckersley (2005) claims that sources of bias are countless and social desirability is strong in many self-reports wellbeing studies.

This study assesses recent and relevant studies on human interrelationships with other humans largely conducted in Malaysia. The theoretical findings help in determining the most appropriate dimensions and indicators of human interrelationships with other humans for Malaysia. Selected findings from recent subjective well-being studies from the year 2010 onwards were used to capture the variables involved in human interrelationships with the environment. The purpose of limiting the sources is to establish parameters in determining the patterns of recent findings on subjective well-being studies, particularly in Malaysia. The selection of the papers depends on the relevance of the papers in examining the personal, relational, organizational and communal well-being as well as the addressed dynamics and factors involved in human interrelationships with the environment. The identified issues, dynamics, and factors relate to the discovered potential indicators of human interrelationships with other humans. 
PLANNING MALAYSIA

Journal of the Malaysia Institute of Planners (2017)

\section{SUSTAINABLE WELLBEING}

Sustainable well-being entails sustainability towards achieving wellbeing (Dodge, Huyton \& Sanders, 2012; O'Riordan, 2014). The approach of sustainable wellbeing is to place maintenance and expansion of wellbeing onto a sustainable basis where it is being provided unsustainably in the present (Holdren, 2007; Dodge et. al, 2012; O'Riordan, 2014). In other words, sustainable wellbeing is achieving wellbeing without compromising others' ability to achieve their wellbeing. 'Others' is about the present society, the future generation, and the surrounding environment. Sustainable well-being offers potential of more comprehensive wellbeing indicators which accounts for a long term use.

Sociality is an important temperament of human existence, a theory acknowledged as far back as Aristotle. Social connectedness is multi-faceted. Well-being studies employing quantitative analysis have been revealing three dimensions where people experience socially connected (Kjell, 2011; Haworth \& Hart, 2007). The experience manifests young and middle-age adults and does not differ across ethnicities. The dimensions are intimate connectedness, relational connectedness and collective connectedness. Intimate connectedness reflects the fulfilment of social connection at a personal level and often associates with marital status. Related connectedness indicates fulfilment in the needs of close friendship and often measured by the frequency of contact with friends and family relatives. Collective connectedness recognizes the fulfilment in the sense of belonging to a group and often measured in the number of voluntary memberships. Human has accessed and adapted to a diverse source of relationship opportunities. Satisfaction of one relationship are interconnected with satisfaction with other relationships. Humans seek fulfilments from a wide array of relationships domains. It is within the human nature to want be close and valued unfailingly over time.

\section{HUMAN WELLBEING IN MALAYSIA}

Many subjective well-being studies have been centred in the Western individualistic countries. The Eastern people tend to have its place in collectivistic society. Collectivistic values have a significant influence on things that make Eastern people happy (Lu \& Shih, 1997). The Western ideal has placed significant emphasis on individualism and liberalism in achieving well-being. The Western ideals greatly differ from collectivistic cultures that highly regard harmonious relations with other members of the society (Lu \& Gilmour, 2004; $\mathrm{Lu} \&$ Shih, 1997). The collectivistic Confucian-based societies particularly Koreans, Chinese and Japanese held moderation as greater esteem than extremism. That is, extreme happiness was not ideal in collectivistic culture ( $\mathrm{Lu}$ et al., 2001). Nevertheless, while Eastern cultures would provide significant knowledge to well-being studies, a significant majority of the studies focused on Chinese and Japanese. There was a lack of well-being studies on Eastern Muslims 
Aisyah Abu Bakar, Mariana Mohamed Osman, Syahriah Bachok, Ismawi Zen, Alias Abdullah, \& Muhammad Faris Abdullah A Theoretical Assessment on Sustainable Wellbeing Indicators for People Interrelationships

countries such as Malaysia. Table 1, Table 2, Table 3, Table 4 and Table 5 show findings from selected studies in Malaysia. The findings were categorized under Overall Well-Being, Personal Well-Being, Relational Well-Being, Organizational Well-Being and Communal Well-Being.

Table 1 Overall Well-Being

\begin{tabular}{l}
\hline Summary of Findings \\
The highest source of happiness for both Malaysian and Indonesian \\
respondents were family. The result demonstrated how Malaysian and Jaafara et \\
Indonesian societies were naturally inclined to collectivistic values that al., 2012 \\
place family and group welfare before personal contentment. Sources of \\
There were significant inter-correlations between well-being domains: (i) \\
standard of living, (ii) health, (iii) life achievements, (iv) personal Clark et al., \\
relationships, (v) personal safety, (vi) feeling part of the community, (vii) 2014 \\
future security, and (viii) life as a whole.
\end{tabular}

Table 2 Personal Well-Being

\begin{tabular}{ll}
\hline Summary of Findings & Authors \\
\hline $\begin{array}{l}\text { Personality traits influence relationships between work-family conflicts } \\
\text { and job satisfaction. }\end{array}$ & $\begin{array}{l}\text { Hashim et } \\
\text { al., } 2012\end{array}$ \\
$\begin{array}{l}\text { There exists a positive and significant correlation between personal well- } \\
\text { being and religiosity. The well-being also shows significant positive }\end{array}$ & $\begin{array}{l}\text { Achour et } \\
\text { al., } 2014\end{array}$ \\
correlations with (i) beliefs and worship, and (ii) prayer. & $\begin{array}{l}\text { Sipon et al., } \\
\text { There was a significant relationship between stress and coping, and } \\
\text { religion was recognized as most apparent source of coping skills. }\end{array}$ \\
$\begin{array}{l}\text { Holistic model for well-being of Muslim women acknowledged that } \\
\text { spiritual well-being as the central of the well-being model that transcends } \\
\text { other well-being dimensions. }\end{array}$ & $\begin{array}{l}\text { Hassan, } \\
2015\end{array}$ \\
\hline
\end{tabular}

Table 3 Relational Well-Being

\begin{tabular}{|c|c|}
\hline \multirow{2}{*}{\multicolumn{2}{|c|}{$\begin{array}{ll}\text { Summary of Findings } & \text { Authors } \\
\text { Family well-being were predicted by (i) resiliency, (ii) safety, (iii) } \\
\text { savings, (iv) healthy lifestyle, (v) time with family, (vi) work-family M. Noor et al., } \\
\text { balance, (vii) importance of religion, (viii) number of bedrooms at } 2012 \\
\text { home, (ix) debt, and (x) childcare. }\end{array}$}} \\
\hline & \\
\hline $\begin{array}{l}\text { Family life satisfaction was a multidimensional construct consisting (a) } \\
\text { family functioning, (b) family resilience, and (c) time with family. }\end{array}$ & $\begin{array}{l}\text { Abu Rahim et } \\
\text { al., } 2013\end{array}$ \\
\hline $\begin{array}{l}\text { Out of } 2,640 \text { number of women interviewed, } 85 \% \text { of them stated that } \\
\text { they had never experienced violence while } 15 \% \text { indicated they had } \\
\text { experienced some types of violence. } 5 \% \text { of them experienced physical } \\
\text { violence, } 7.8 \% \text {, emotional violence; and } 1.7 \% \text {, sexual violence. } 8 \% \text { of } \\
\text { them experienced violence committed by their living partners. }\end{array}$ & \\
\hline $\begin{array}{l}\text { Tangible and emotional support significantly associated with well- } \\
\text { being. Social embeddedness significantly mediates the effect of social } \\
\text { cohesion upon well-being through tangible support and through }\end{array}$ & \\
\hline
\end{tabular}


emotional support. Thus suggests that social cohesion leads to increased social embeddedness, which contribute to inducing tangible support and emotional support, thus affect well-being.

Table 4 Organizational Well-Being

\begin{tabular}{ll}
\hline Summary of Findings & Authors \\
\hline $\begin{array}{l}\text { (i) Job satisfaction, (ii) job involvement, and (iii) job security explained } \\
57 \% \text { variance of Quality of Work (QWL). }\end{array}$ & $\begin{array}{l}\text { Noor and } \\
\text { Abdullah, } \\
2011\end{array}$ \\
\hline $\begin{array}{l}\text { Two directions of work-family conflicts were work interference with } \\
\text { family (WIF), and family interference with work (FIW). Level of WIF is } \\
\text { higher than level of FIW. }\end{array}$ & $\begin{array}{l}\text { Panatika et } \\
\text { al., } 2011\end{array}$ \\
\hline $\begin{array}{l}\text { There was (i) a strong positive relationship between self-esteem and } \\
\text { satisfaction outcome, (ii) a moderate negative relationship between self- Wan Rashida } \\
\text { esteem and work-family conflict and (iii) a weak negative relationship et al., } 2012 \\
\text { between work-family conflict and satisfaction outcome. }\end{array}$ \\
\hline $\begin{array}{l}\text { Gender, marital status, age groups, education levels, monthly income and Mokhtar et } \\
\text { working experiences were not predictors of financial well-being. }\end{array}$ \\
\begin{tabular}{l} 
al., 2014 \\
\hline
\end{tabular}
\end{tabular}

Table 5 Communal Well-Being

\begin{tabular}{ll}
\hline Summary of Findings & Authors \\
\hline $\begin{array}{l}\text { Neighbourhood location and surroundings influenced neighbourhood } \\
\text { satisfaction, thus affecting residents QoL. }\end{array}$ & $\begin{array}{l}\text { Sedaghatnia } \\
\text { et al., } 2013\end{array}$ \\
\hline $\begin{array}{l}\text { Social capital had positive consequences on family and societal well- } \\
\text { being, strengthen neighbourhood and increase quality of life. The level } \\
\text { of social capital was influenced by how long the neighbourhood has been } \\
\text { established, the diversity composition of residents, locations and the Hamdan et } \\
\text { surrounding developments. Collective actions and cooperation were al., } 2014 \\
\text { negatively correlated with sense of cohesion and inclusion High density } \\
\text { neighbourhood result in loneliness as residents felt retracted from one } \\
\text { another while dealing with 'sensory overload'. }\end{array}$ \\
$\begin{array}{l}\text { There was a high internal reliability in six components of social capital.. } \\
\text { al., 2014 }\end{array}$ \\
\hline
\end{tabular}

Table 1, Table 2, Table 3, Table 4 and Table 5 summarize the findings and highlight important variables involved from the selected articles of human interrelationships with other human studies. The findings provide understanding on how human-human studies are conducted and the dynamics or relationships between the variables tested in the research. Highlighted key variables from each article can be used to formulate the indicators of human interrelationships with other humans.

\section{DIMENSIONS OF HUMAN-ENVIRONMENT INTERRELATIONSHIPS}

Dimensions of human interrelationships with other humans refer to the locations where variables of human interrelationships with other humans manifested. That 
Aisyah Abu Bakar, Mariana Mohamed Osman, Syahriah Bachok, Ismawi Zen, Alias Abdullah, \& Muhammad Faris Abdullah A Theoretical Assessment on Sustainable Wellbeing Indicators for People Interrelationships

is the settings or conditions to which positive interaction between human and other humans occur. There were four dimensions of human interrelationships with other humans recognized based on the explored findings of Malaysia wellbeing studies. The first dimension is Personal Empowerment which manifests in opportunity to exercise control, voice and choice (Hashim et al., 2012; Jaafara et al., 2012; Achour et al., 2014; Sipon et al., 2014; Clark et al., 2014; Hassan, 2015). The second dimension is Positive Relations which manifests in positive experience of trust, nurturance and affection (Noor et al., 2012; Jaafara et al., 2012; Abu Rahim et al., 2013; Shuib et al., 2013; Momtaz et al., 2014; Clark et al., 2014). The third dimension is Organizational Opportunity manifests in traditions of inclusions, learning and horizontal structures (Noor \& Abdullah, 2012; Panatika et al., 2011; Rashida et al., 2012; Jaafara et al., 2012; Mokhtar et al., 2015; Clark et al., 2014). The fourth and final dimension is Community Movement which manifests in maximization of social supports and benefits throughout life cycle (Jaafara et al., 2012; Sedaghatnia et al., 2013; Hamdan et al., 2014; Marzuki et al., 2014; Clark et al., 2014).

\section{Potential Indicators of Human-Environment Interrelationships}

Based on the literature reviews and findings from articles gathered from the potential subjective indicators are developed (Table 6) and categorized under the four dimensions of human interrelationships with other humans.

Table 6 Potential Indicators for Human Interrelationships with Other Humans

\begin{tabular}{|c|c|c|c|}
\hline $\begin{array}{l}\text { Dimen- } \\
\text { sions }\end{array}$ & $\begin{array}{l}\text { Manifesta- } \\
\text { tion }\end{array}$ & Potential Indicators & Sources \\
\hline 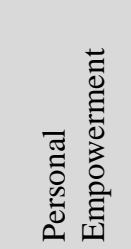 & $\begin{array}{l}\text { opportunity } \\
\text { to exercise } \\
\text { control, } \\
\text { voice and } \\
\text { choice }\end{array}$ & $\begin{array}{l}\text { self-determination, sense of } \\
\text { control, self-efficacy, physical } \\
\text { health, mental health, optimism, } \\
\text { meaning and spirituality }\end{array}$ & $\begin{array}{l}\text { Hashim et al., 2012; } \\
\text { Jaafara et al., 2012; } \\
\text { Achour et al., 2014; } \\
\text { Sipon et al., 2014; Clark } \\
\text { et al., 2014; Hassan, } \\
2015\end{array}$ \\
\hline$: \stackrel{\substack{0 \\
:}}{\stackrel{0}{0}}$ & $\begin{array}{l}\text { positive } \\
\text { experience } \\
\text { of trusts, } \\
\text { nurturance } \\
\text { and } \\
\text { affection }\end{array}$ & $\begin{array}{l}\text { caring/love/affection, respect for } \\
\text { diversity, reciprocity, nurturance } \\
\text { and affection, emotional support, } \\
\text { collaboration, democratic } \\
\text { participation in decision-making }\end{array}$ & $\begin{array}{l}\text { Noor et al., 2012; } \\
\text { Jaafara et al., 2012; Abu } \\
\text { Rahim et al., 2013; } \\
\text { Shuib et al., 2013; } \\
\text { Momtaz et al., 2014; } \\
\text { Clark et al., } 2014\end{array}$ \\
\hline 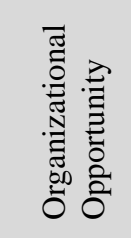 & $\begin{array}{l}\text { inclusions, } \\
\text { learning } \\
\text { and } \\
\text { horizontal } \\
\text { structures }\end{array}$ & $\begin{array}{l}\text { respect for diversity, democratic } \\
\text { participation, collaborative } \\
\text { relationships, engagement, } \\
\text { good communication, clear roles } \\
\text { and productivity, learning } \\
\text { opportunities }\end{array}$ & $\begin{array}{l}\text { Noor \& Abdullah, 2012; } \\
\text { Panatika et al., 2011; } \\
\text { Rashida et al., 2012; } \\
\text { Jaafara et al., 2012; } \\
\text { Mokhtar et al., 2015; } \\
\text { Clark et al., } 2014\end{array}$ \\
\hline
\end{tabular}


maximizati

on of social

supports

and

benefits,

and

availability

of supports

throughout

life cycle equitable allocation if bargaining, powers, resources and obligations in society, gender and race equality, universal access to high quality educational, health and recreational facilities, affordable housing, employment opportunities, access to nutritious foods at reasonable prices, public transportation, clean environment, safety and peace
Jaafara et al., 2012;

Sedaghatnia et al., 2013;

Hamdan et al., 2014;

Marzuki et al., 2014;

Clark et al., 2014

Table 6 shows the potential indicators of human interrelationships with other humans that are yet to be statistically confirmed. The potential indicators are gathered from the literature reviews and summarized findings of selected subjective well-being studies in Malaysia. The potential indicators are organized under dimensions of the interdependencies between human and other humans. The dimensions are the location where the indicators are found. The manifestation indicates the expression or demonstration of the dimensions. Finally, the indicators proxy the manifestations and dimensions of the interdependencies. In other words, the indicators provide ways for the interdependencies between human and other humans to be gauged.

\section{CONCLUSION}

This exploratory review focused on developing potential quantifiable subjective indicators of human interrelationships with other humans at the local scale. The indicators are valuable to measure the readiness of the locals in embracing sustainable well-being in their lifestyle. The indicators are also useful to indicate the extent of current lifestyles that incorporates relations between human and other humans. Other opportunities for use include additional indicators for social well-being components in the national well-being reports. The indicators can serve as helpful data for policy review which before was difficult to evaluate due to lack of unquantifiable data (MWI, 2013; MQLI, 2011; MQLI, 2004; MQLI 2002).

The limitation of this research is the lack of empirical data to prove the dimensions of human interrelationships with other humans. The study will also assess more relevant and reliable published academic sources especially from social indicator researches towards finalizing the subjective indicators of human interrelationships with other humans (Bakar et al., 2015a; 2015b; 2015c). Apart from establishing potential indicators, reviewing selected articles enable the researcher to distinguish the pattern of subjective well-being research particularly in Malaysia. The next challenge of the study is to substitute the potential indicators into questionnaire inquiries in comprehensive yet concise manner, 
Aisyah Abu Bakar, Mariana Mohamed Osman, Syahriah Bachok, Ismawi Zen, Alias Abdullah, \& Muhammad Faris Abdullah A Theoretical Assessment on Sustainable Wellbeing Indicators for People Interrelationships

which are understandable to the targeted respondents. The data obtained and analysed from the questionnaires will determine if the dimensions of human interrelationships do in fact multivariately correlated and contribute to sustainable well-being.

\section{ACKNOWLEDGEMENTS}

This research was supported by MyGRANTS. This paper was presented at 2015 Asia Pacific International Conference on Environment-Behaviour Studies.

\section{REFERENCES}

Abu Rahim, A. R., Ishak, I., Mohd Shafie, S. A., \& Shafiai, R. M. (2013). Factors influencing family life satisfaction among parents in Malaysia: the structural equation modeling approach (SEM). IOSR Journal of Humanities and Social Science, 17(4), 78-85.

Achour, M., Grine, F., Mohd Nor, M. R., \& MohdYusoff, M. Y. Z. (2014). Measuring religiosity and its effects on personal well-being: a case study of Muslim female academicians in Malaysia. Journal of Religion and Health. doi:10.1007/s10943014-9852-0

Bakar, A. A., Osman, M. M., Bachok, S., \& Abdullah, A. (2015a, September). An exploratory review: human interrelationships with environment. In Asia Pacific International Conference on Environment-Behaviour Studies.

Bakar, A. A., Osman, M. M., Bachok, S., \& Ibrahim, M. (2015b, September). An exploratory review: human interrelationships with other humans. In Asia Pacific International Conference on Environment-Behaviour Studies.

Bakar, A. A., Osman, M. M., Bachok, S., \& Ibrahim, M. (2015c, November). Sustainable well-being subjective indicators: human interdependencies with other humans and with the environment. In 6th International Conference on Sustainable Future for Human Security.

Clark, M., Amar-Singh, H. S., \& Hashim, L. (2014). The subjective well-being of Malaysian school children: grade level, gender and ethnicity. Psychology, 5, $1453-1462$.

Dodge, R., Daly, A., Huyton, J., \& Sanders, L. (2012). The challenge of defining wellbeing. International Journal of Wellbeing, 3(2), 222-235.

Eckersley, R. (2015). Beyond inequality: Acknowledging the complexity of social determinants of health. Social Science \& Medicine, 147, 121-125.

Geller, E. S. (2015). Why we need humanistic behaviorism. ISHN, 49(10), 52.

Hamdan, H., Yusof, F., \& Marzukhi, M. A. (2014). Social capital and quality of life in urban neighborhoods high density housing. Procedia - Social and Behavioral Sciences, 153, 169-179. doi: 10.1016/j.sbspro.2014.10.051

Hashim, N., Ishar, N. I. M., Rashid, W. E. W., \& Masodi, M. S. (2012). Personality traits, work-family conflict and job satisfaction: items validity using rasch measurement approach. Procedia - Social and Behavioral Sciences, 65(ICIBSoS), 1013-1019. doi: 10.1016/j.sbspro.2012.11.235 
Hassan, S. A. (2015). Islamic transcendental wellbeing model for Malaysian Muslim women: implication on counselling. Asian Social Science, 11(21), 331-341. doi:10.5539/ass.v11n21p331

Haworth, J., \& Hart, G. (2007). Webs of well-being: the interrelationships of personal, relational, organizational and communal well-being. In Well-being: Individual, community and social perspectives. Basingstoke: Palgrave Macmillan.

Holdren, J. P. (2007). Energy and sustainability. Science, 315(5813), 737-737.

Jaafara, J. L., Idris, M. A., Ismuni, J., Fei, Y., Jaafar, S., Ahmad, Z., \& Sugandi, Y. S (2012). The sources of happiness to the Malaysians and Indonesians: data from a smaller nation. Procedia - Social and Behavioral Sciences, 65(ICIBSoS), 549556. doi:10.1016/j.sbspro.2012.11.164

Kjell, O. N. (2011). Sustainable well-being: A potential synergy between sustainability and well-being research. Review of General Psychology, 15(3), 255.

Lu, L., \& Shih, J. B. (1997). Sources of happiness: a qualitative approach. Journal of Social Psychology, 137, 181-187.

Lu, L., \& Gilmour, R. (2004). Culture, self and ways to achieve SWB: a cross-cultural analysis. Journal of Psychology in Chinese Societies, 5, 51-79.

Lu, L., R. Gilmour, S.F. Kao, T.H. Eng, C.H. Hu, J.G. Chern, S.W. Huang \& Shih, J. B. (2001). Two ways to achieve happiness: when the east meets the west. Personality and Individual Differences, 30, 1161-1174.

Malaysia Quality of Life Report [MQLI] (2004). The Malaysian Quality of Life Index 2004. Putrajaya: Economic Planning Unit, Prime Minister's Department.

Malaysia Quality of Life Report [MQLI] (2011). The Malaysian Quality of Life Index 2011. Putrajaya: Economic Planning Unit, Prime Minister's Department.

Malaysia Wellbeing Report [MWI] (2013). The Malaysian Wellbeing Index 2013. Putrajaya: Economic Planning Unit, Prime Minister's Department.

Malaysian Quality of Life Index [MQLI] 2002. The Malaysian Quality of Life Index 2002. Putrajaya: Economic Planning Unit, Prime Minister's Department.

Marzuki, N. A., Ahmad, N. A., Hamid, A. S. A., \& Ishak, M. S. (2014). Community social capital in Malaysia: a pilot study. Asian Social Science, 10(12), 202-209. doi:10.5539/ass.v10n12p202

Mokhtar, N., Husniyah, a. R., Sabri, M. F., \& Abu Talib, M. (2015). Financial well-being among public employees in Malaysia: a preliminary study. Asian Social Science, 11(18), 49-54. doi:10.5539/ass.v11n18p49

Momtaz, Y. A., Haron, S. A., Ibrahim, R., \& Hamid, T. A. (2014). Social embeddedness as a mechanism for linking social cohesion to well-being among older adults : moderating effect of gender. Clinical Interventions in Aging, 3, 863-870.

Noor, N. M., Gandhi, A. D., Ishak, I., \& Wok, S. (2012). Development of indicators for family well-being in Malaysia. Social Indicator Research, 115, 279-38. doi:10.1007/s11205-012-0219-1

Noor, S. M., \& Abdullah, M. A. (2012). Quality work life among factory workers in Malaysia. Procedia - Social and Behavioral Sciences, 35(December), 739-745. Retrieved from http://dx.doi.org/10.1016/j.sbspro.2012.02.144

O'Riordan, T. (2014). Sustainability beyond austerity: possibilities for a successful transition to a wellbeing society. Análise Social, 211, 497-520. 
Aisyah Abu Bakar, Mariana Mohamed Osman, Syahriah Bachok, Ismawi Zen, Alias Abdullah, \& Muhammad Faris Abdullah

A Theoretical Assessment on Sustainable Wellbeing Indicators for People Interrelationships

Panatika, S. A. B., Badri, S. K. Z., Rajab, A., Rahman, H. A., \& Shah, I. M. (2011). The impact of work family conflict on psychological well-being among school teachers in Malaysia. Procedia - Social and Behavioral Sciences, 29, 15001507. doi:10.1016/j.sbspro.2011.11.390

Prilleltensky, I., \& Fox, D. R. (2007). Psychopolitical literacy for wellness and justice. Journal of Community Psychology, 35(6), 793-805.

Rashida, W. E. W., Nordin, M. S., Omar, A., \& Ismail, I. (2012). Work Family Conflict: The Link between Self-Esteem and Satisfaction Outcomes. Procedia - Social and Behavioral Sciences, 65(ICIBSoS), 564-569. doi:10.1016/ j.sbspro.2012.11.166

Sedaghatnia, S., Lamit, H., Ghahramanpouri, A., \& Mohamad, S. (2013). An evaluation of residents $^{\text {ee }}$ quality of life through neighborhood satisfaction in Malaysia. Environmental Management and Sustainable Development, 2, 114-125.

Shuib, R., Endut, N., Ali, S. H., Osman, I., Abdullah, S., Oon, S. W., \& Shahrudin, S. S. H. (2013). Domestic violence and women's well-being in Malaysia: issues and challenges conducting a national study using the WHO multi-country questionnaire on women's health and domestic violence against women. Procedia - Social and Behavioral Sciences, 91, 475-488. doi:10.1016/ j.sbspro.2013.08.445

Sipon, S., Nasrah, S. K., Nazli, N. N. N. N., Abdullah, S., \& Othman, K. (2014). Stress and religious coping among flood victims. Procedia - Social and Behavioral Sciences, 140, 605-608. doi:10.1016/j.sbspro.2014.04.478. 